\title{
SOME EFFECTS OF LOW ATMOSPHERIC PRESSURE ON RATS ${ }^{1}$
}

\author{
By DANIEL C. DARROW AND ERNEST L. SARASON \\ (From the Departments of Pediatrics and Pathology of the Yale University School of \\ Medicine, New Haven)
}

(Received for publication December 23, 1942)

This paper reports results obtained on rats subjected to prolonged exposure to low atmospheric pressure. Histological studies reveal depletion of adrenocortical lipid during the early phase of exposure. Chemical analyses are presented of the muscle and liver in rats exposed to low atmospheric pressure while on a normal diet, after a diet low in potassium, and after receiving desoxycorticosterone acetate. Deficit of body potassium-the typical change in muscle produced by some of the cortical steroids-decreases the resistance to low atmospheric pressure. Furthermore, low atmospheric pressure aggravates the tendency of desoxycorticosterone acetate to produce cardiac lesions. Some features of the muscle analyses suggest overactivity of the adrenal cortex during exposure to low atmospheric pressures.

\section{METHODS}

Only male albino rats of the Wistar strain, weighing from 200 to 250 grams, were used. The basic feed was Purina Fox Chow which contains $16 \mathrm{mM}$ of $\mathrm{K}$ per 100 grams. The diet low in potassium contained lactalbumin, sucrose, Crisco, yeast, and a salt mixture and has been previously described (1). It contained $1.6 \mathrm{mM}$ per 100 grams. Desoxycorticosterone acetate (DOCA) was injected subcutaneously in doses of $2 \mathrm{mgm}$. daily for 14 days before exposure to low atmospheric pressures and also during exposure. For this purpose, crystalline desoxycorticosterone acetate was dissolved in hot alcohol and precipitated in a fine suspension which contained 2 $\mathrm{mgm}$. of the compound per cc. in 5 per cent alcoholic physiological saline.

The rats were exposed to low barometric pressures in bell jars with valves which maintained a given reduced pressure within fairly narrow limits and permitted adequate renewal of air, so that the effect was essentially reduction of atmospheric pressure. 2 The animals were kept continuously at the reduced pressure, except for the

\footnotetext{
1 Aided by a grant from the Fluid Research Fund of the Yale University School of Medicine.

2 The decompression chambers were kindly placed at our disposal by the Department of Physiology. Determination of the rate of ventilation showed that significant accumulation of carbon dioxide would not develop during these experiments.
}

hour daily needed for cleaning the cages and replacing food and water. Only two pressures were used: one equivalent to an elevation of 20,000 feet above sea level and the other equivalent to 25,000 feet.

About one-half hour after being removed from the bell jars, the rats were first anesthetized with nembutal, then one gastrocnemius and a piece of liver were removed for determination of glycogen, and finally, the rats were bled to death by withdrawing blood from the abdominal aorta. Blood, muscle, and liver were analysed chemically as in previous studies (2). The adrenals were placed in 4 per cent solution of formaldehyde for 2 days and weighed to the nearest milligram after removal of adventitia. Paraffin sections were stained with hematoxyline and eosin; frozen sections (10 to 15 microns thick) were stained with Sudan IV. The phenylhydrazine and digitonin techniques of Bennett (3) were used in selected cases to demonstrate corticosteroids and cholesterol, respectively. Since, in rats, the distribution of lipid (Sudan IV staining) is essentially the same as the distribution of cholesterol (digitonin technique) or corticosteroids (phenylhydrazine technique), the simple Sudan IV staining serves to indicate distribution of all fractions of cortical lipids.

\section{RESULTS}

The interpretation of the results is complicated by the fact that exposure to low atmospheric pressure leads to varying degrees of starvation and loss of weight and, for this reason, fasting controls are necessary. At 20,000 feet, the rats were distressed during the first 2 to 3 days but gradually became acclimatized so that they appeared fairly well at the end of the week. No food was eaten during the first day but the appetite gradually returned, so that approximately normal amounts were taken after the third day. In this respect, the rats receiving DOCA were different from those of the other groups, for they remained distressed and never recovered their appetite, even at 20,000 feet. One rat receiving DOCA died on the third day at 20,000 feet while none of the others died at this level. All rats remained extremely distressed at 25,000 feet and practically no food was taken although water was drunk. No rat receiving DOCA was able to sur- 
vive 24 hours at 25,000 feet. Table I shows the weight losses expressed in per cent of initial body weight. These values may be considered measures of the spontaneous fasting as well as the degree of distress during the exposure to low atmospheric pressures.

\section{Adrenal weight}

The data on the weights of the adrenals are summarized in Table I. Since adrenal weight varies directly with body weight $(4,5)$ and since adrenals show minimal changes in size with transient fluctuations in body weight (5), the adrenal weights are expressed per unit of initial body weight. During the first 2 days at 25,000 feet, the adrenals are statistically enlarged in the rats fed the diet low in potassium but are normal in this group at the end of a week at this pressure. One normal rat exposed for 7 days at 25,000 feet shows absolute enlargement but this rat is apparently an exception since he showed considerably more distress and loss of weight than the other rats of this group. Otherwise, the variations in adrenal size are within the range of the fasted controls. While the number of observations is small, the data are sufficient to show that great

TABLE I

Adrenal sise and cortical lipid

\begin{tabular}{|c|c|c|c|c|c|c|}
\hline & \multirow{2}{*}{$\begin{array}{c}\text { Number } \\
\text { of rats }\end{array}$} & \multirow{2}{*}{ Period of exposure } & \multirow{2}{*}{ Weight loss } & \multicolumn{2}{|c|}{ Ratio of adrenal to body weight } & \multirow{2}{*}{ Cortical lipid } \\
\hline & & & & Initial weight & Final weight & \\
\hline \multirow{2}{*}{\multicolumn{7}{|c|}{ Rats kept at sea level }} \\
\hline & & & & & & \\
\hline $\begin{array}{l}\text { Normal diet } \\
\text { Low } \mathrm{K} \text { diet } \\
\text { DOCA } 14 \text { days }\end{array}$ & $\begin{array}{r}8 \\
10 \\
5\end{array}$ & & & $\begin{array}{l}0.145 \pm 0.005 \\
0.133 \pm 0.003 \\
0.131 \pm 0.005\end{array}$ & & \\
\hline $\begin{array}{l}\text { Fasted } 1 \text { day } \\
\text { Fasted } 2 \text { days } \\
\text { Fasted } 7 \text { days }\end{array}$ & $\begin{array}{l}\mathbf{3} \\
\mathbf{3} \\
\mathbf{3}\end{array}$ & & $\begin{array}{l}12 \\
15 \\
28\end{array}$ & $\begin{array}{l}0.151 \pm 0.005 \\
0.164 \pm 0.004 \\
0.158 \pm 0.004\end{array}$ & $\begin{array}{l}0.172 \\
0.194 \\
0.224\end{array}$ & \\
\hline \multicolumn{7}{|c|}{ Rats exposed to low atmospheric pressures } \\
\hline $\begin{array}{l}\text { Normal rats } \\
20,000 \text { feet }\end{array}$ & $\begin{array}{l}3 \\
3 \\
3\end{array}$ & $\begin{array}{l}1 \text { day } \\
2 \text { days } \\
7 \text { days }\end{array}$ & $\begin{array}{r}9 \\
11 \\
11\end{array}$ & $\begin{array}{l}0.155 \pm 0.013 \\
0.154 \pm 0.008 \\
0.131 \pm 0.013\end{array}$ & $\begin{array}{l}0.171 \\
0.172 \\
0.142\end{array}$ & \\
\hline $\begin{array}{l}\text { Normal rats } \\
25,000 \text { feet }\end{array}$ & $\begin{array}{l}2 \\
2 \\
2 \\
3 \\
3 \\
3 \\
1 *\end{array}$ & $\begin{array}{l}1 \text { hour } \\
2 \text { hours } \\
5 \text { hours } \\
1 \text { day } \\
2 \text { days } \\
7 \text { days } \\
7 \text { days }\end{array}$ & $\begin{array}{r}2 \\
3 \\
3 \\
13 \\
18 \\
24 \\
37\end{array}$ & $\begin{array}{l}0.128 \pm 0.003 \\
0.152 \pm 0.010 \\
0.141 \pm 0.010 \\
0.136 \pm 0.002 \\
0.158 \pm 0.002 \\
0.151 \pm 0.004 \\
0.204\end{array}$ & $\begin{array}{l}0.131 \\
0.157 \\
0.148 \\
0.155 \\
0.192 \\
0.198 \\
0.325\end{array}$ & $\begin{array}{l}+++t \\
++t \\
++ \\
+ \\
0 \\
0^{+}++t\end{array}$ \\
\hline $\begin{array}{l}\text { Low } \mathrm{K} \text { diet } \\
20,000 \text { feet }\end{array}$ & $\begin{array}{l}4 \\
2 \\
2\end{array}$ & $\begin{array}{l}1 \text { day } \\
2 \text { days } \\
7 \text { days }\end{array}$ & $\begin{array}{r}10 \\
7 \\
10\end{array}$ & $\begin{array}{l}0.143 \pm 0.013 \\
0.131 \pm 0.014 \\
0.115 \pm 0.003\end{array}$ & $\begin{array}{l}0.159 \\
0.142 \\
0.128\end{array}$ & $\begin{array}{l}t+ \\
+t \\
t+t+\end{array}$ \\
\hline $\begin{array}{l}\text { Low } \mathrm{K} \text { diet } \\
25,000 \text { feet }\end{array}$ & $\begin{array}{l}3 \\
\mathbf{3} \\
\mathbf{3}\end{array}$ & $\begin{array}{l}1 \text { day } \\
2 \text { days } \\
7 \text { days }\end{array}$ & $\begin{array}{r}10 \\
9 \\
16\end{array}$ & $\begin{array}{l}0.196 \pm 0.012 \\
0.204 \pm 0.010 \\
0.159 \pm 0.009\end{array}$ & $\begin{array}{l}0.216 \\
0.224 \\
0.189\end{array}$ & $\begin{array}{l}+t \\
+++ \\
++\end{array}$ \\
\hline $\begin{array}{l}\text { DOCA } \\
20,000 \text { feet }\end{array}$ & $\begin{array}{l}3 \\
\mathbf{3} \\
\mathbf{3}\end{array}$ & $\begin{array}{l}1 \text { day } \\
2 \text { days } \\
7 \text { days }\end{array}$ & $\begin{array}{r}8 \\
13 \\
16\end{array}$ & $\begin{array}{l}0.146 \pm 0.011 \\
0.157 \pm 0.066 \\
0.135 \pm 0.007\end{array}$ & $\begin{array}{l}0.159 \\
0.208 \\
0.150\end{array}$ & $\begin{array}{l}++ \\
0 \\
+++t\end{array}$ \\
\hline $\begin{array}{l}\text { DOCA } \\
25,000 \text { feet }\end{array}$ & $6 * *$ & 1 day & 8 & $0.147 \pm 0.005$ & & $+t$ \\
\hline $\begin{array}{l}\mathrm{KCl} \text { in water } \\
25,000 \text { feet }\end{array}$ & 2 & 6 days & 28. & $0.136 \pm 0.014$ & 0.190 & $+t+t$ \\
\hline
\end{tabular}

Cortical lipid: ++++ , normal; +++ , slight reduction; ++ , moderate reduction; + , extensive reduction; 0 , apparent absence.

* Absolute hypertrophy and lipid depletion in rat exhibiting extreme loss of weight.

* 5 of 6 rats died in less than 12 hours. 
changes in adrenal size do not regularly accompany prolonged exposure to pressures equivalent to 20 ,000 or 25,000 feet during the first 7 days.

\section{Adrenocortical lipids}

The histologic appearance of the adrenals is represented in Table $I$ in 5 degrees: ++++ indicating the normal appearance of the Sudan IV stain (see Figure 1, Part 1);,+++++ , and + , stages in the partial depletion of cortical lipids (see Figure 1, Parts 2, 3, and 4) ; 0, apparently complete loss of cortical lipid. Histologically, the adrenals present marked evidence of loss of lipid during the early period of exposure but with subsequent recovery. At 20,000 feet, the loss after 1 or 2 days is definite in normal rats, somewhat greater in rats on the diet low in potassium, and very marked in the rats receiving DOCA. On the second day, the adrenals of rats receiving DOCA show practically no sudanophilic staining. In this group, the loss of cortical lipid is in addition to the depletion in a narrow peripheral zone of the glomerulosa which has been described following injections of the synthetic cortical compound (6). After an exposure of 7 days, all animals able to withstand either pressure show normal lipid patterns in the adrenals. This finding is especially remarkable because, at 25,000 feet, rats are apparently unable to become fully acclimated and would be unable to survive much longer than a week at this pressure.

Studies on normal rats show that the losses of cortical lipid start very early. Although no significant changes are noted at 25,000 feet after 1 hour, the beginnings of focal lipid alterations are quite definite after 2 hours, the sudanophilic material being in smaller droplets as well as less wirlely distributed (Figure 1, Part 2); after 5 hours, depletion of cortical lipid is even more striking (Figure 1, Part 3). Partial recovery is revealed after 3 days' exposure (Figure 1, Part 6 ) and is complete after 7 days (Figure 1, Part 7 ). The use of the digitonin and phenylhydrazine techniques demonstrates that changes in cortical cholesterol and corticosterones parallel the changes in lipid, as revealed by staining with Sudan IV. Thus, the loss of lipid probably starts immediately, attains a maximum in 1 or 2 days when recovery commences, and becomes complete within a week.

\section{Liver and kidney}

Microscopic examinations of the liver and kidneys were made in only a few of the animals in each group. Many of the livers in each group showed extensive vacuolization of parenchymal cells, associated with sudanophilic material in the central portion of the liver lobule, but the typical picture of chronic passive congestion was not encountered. No changes were noted in the kidneys except the relative increase in size when compared to final body we:ght. This finding was to be expected, since kidneys in acute inanition retain their size almost as well as the adrenals. As has been previously pointed out $(7)$, diets low in potassium or treatment with DOCA lead to enlargement of the kidneys. The kidneys were relatively large in rats on the diet low in potassium and in those receiving DOCA but diminished oxygen tension did not alter this state.

\section{Heart}

Histological sections of practically all hearts were studied. No lesions were encountered except in rats receiving desoxycorticosterone acetate. Table II brings together the data which indicate

TABLE II

Cardiac lesions after DOCA

\begin{tabular}{c|c|c|c|c|c}
\hline \hline Diet & Injections & Fast & Low $\mathrm{O}_{2}$ & $\begin{array}{c}\text { Number } \\
\text { of rats }\end{array}$ & $\begin{array}{c}\text { Number of } \\
\text { lesions }\end{array}$ \\
\hline & 1 days & days & days & & \\
$\mathrm{N}$ & 30 & 0 & 0 & 50 & 34 \\
$\mathrm{~N}$ & 14 & 0 & 0 & 7 & 1 \\
$\mathrm{~N}$ & 14 & 1 to 7 & 0 & 8 & 0 \\
$\mathrm{~N}$ & 14 & 0 & 1 to 7 & 8 & 8 \\
$\mathrm{LK}$ & 14 & 0 & 3 & 4 & 0 \\
\hline
\end{tabular}

When fasting or exposure to low oxygen tension was carried out, injections of DOCA (2 mgm. daily) were continued in addition to the preparatory 14 days. $\mathrm{N}$ and $\mathrm{LK}$ refer to normal and low potassium diets, respectively. Exposures were equivalent to an elevation of $20,000 \mathrm{feet}$

that low oxygen tension aggravates the tendency to lesions produced by injections of DOCA. As was previously pointed out (8), lesions can be found in over two-thirds of the rats kept at sea level while receiving DOCA for 30 days, but microscopic lesions are quite rare at sea level when injections are continued for only 14 days, even if a period of fasting is superimposed thereafter. However, lesions ware regularly found-some ex- 


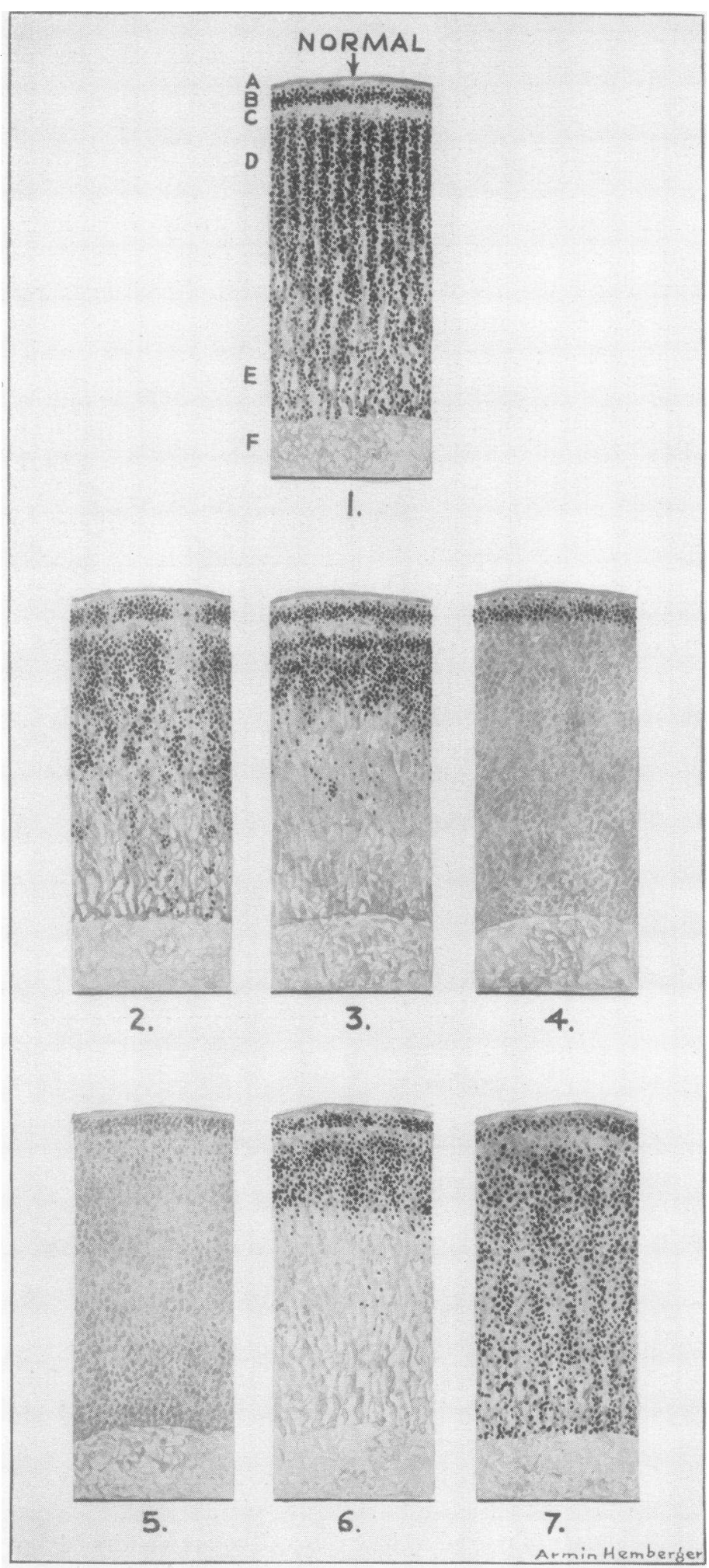

FIG. 1 


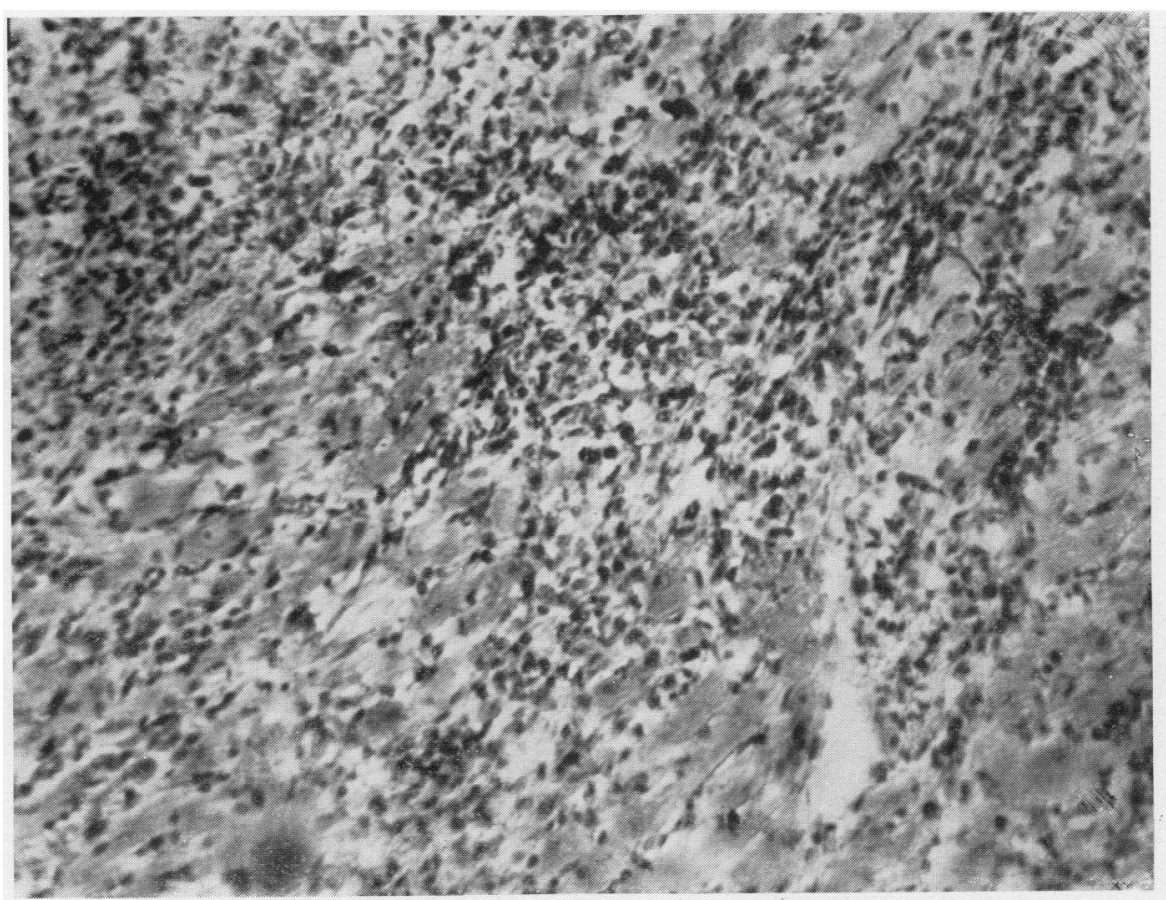

Fig. 2. Rat 31. Photomicrograph of the Heart

This rat received $2 \mathrm{mgm}$. of desoxycorticosterone acetate subcutaneously each day for 14 days; he was exposed to an atmospheric pressure equivalent to an elevation of 20,000 feet for 1 day.

tremely extensive as is shown in the photomicrograph (Figure 2)-when exposure to low oxygen tension was carried out for 1 to 7 days after injections of DOCA. Since lesions were not found when rats had received a diet low in potassium before exposure to low oxygen tensions, depletion of body potassium before exposure is not the sole cause of these lesions. This conclusion follows from the fact that roughly comparable losses of body potassium were produced both by a diet low in potassium and by repeated injections of DOCA. Low oxygen tensions or deficit of carbon dioxide apparently aggravate the tendency to cardiac lesions produced by repeated injections of DOCA.

Fig. 1. Diagrammatic Drawings of Sections from Frozen Adrenals Stained with Sudan IV. Magnified about 25-fold

Part 1. Normal rat adrenal. The black dots represent sudanophilic material. A. Thin, acellular fat-free capsule; B. glomerulosa layer; C. "clear zone" of outer fasciculata; D. outer fasciculata; E. inner fasciculata; F. medulla.

Part 2. Exposure: 25,000 feet for 2 hours. Note the slight reduction of the cortical lipid.

Part 3. Exposure: 25,000 feet for 5 hours. Note the moderate reduction of cortical lipid.

Part 4. Exposure: 25,000 feet for 1 day. Note the complete absence of cortical lipid save for that present in the glomerulosa layer.

Part 5. Exposure: 25,000 feet for 2 days. Note the complete absence of cortical lipid.

Part 6. Exposure : 25,000 feet for 3 days. Note the beginning of return of cortical lipid in the glomerulosa and outer fasciculata.

Part 7. Exposure: 25,000 feet for 7 days. Note the relatively normal lipid pattern of the adrenal cortex. 


\section{CHEMICAL CHANGES IN SERUM AND TISSUES}

The chemical composition of serum, muscle, and liver was determined because of the important changes in serum known to take place and because these changes might be accompanied by alterations in the tissues. Furthermore, the suggestive evidence of overactivity of the adrenal cortex brings up the question of changes characteristic of overactivity or deficiency of these glands.

The muscle and serum analyses are given in Tables III, IV, and V. Note that sodium and chloride of the serum are expressed per liter of ultrafiltrate, while water and potassium are expressed per liter of serum. In the case of $\mathrm{Na}$ and $\mathrm{Cl}$, the concentrations are calculated using the water content and an average Donnan factor of 0.96. These concentrations represent approxi- mately those in extracellular fluid. A similar calculation was not made in the case of potassium since the distribution of this ion is uncertain. Two types of derived data are given in the last 2 columns. The first may be called the extracellular water and was calculated by the following formula :

$$
\left(\mathrm{H}_{2} \mathrm{O}\right)_{e}=\frac{(\mathrm{Cl})_{t}-1}{[\mathrm{Cl}]_{e}} \times 1000
$$

in which $\left(\mathrm{H}_{2} \mathrm{O}\right)_{e}$ is extracellular water in $\mathrm{ml}$.; $(\mathrm{Cl})_{t}$, total tissue chloride in $\mathrm{mM}$; $[\mathrm{Cl}]_{e}$, the concentration of chloride in $\mathrm{mM}$ per liter of an ultrafiltrate of serum. The reason for subtracting 1 is that it represents approximately the chloride that does not behave like extracellular chloride (9, 10). The other derived datum may be called

TABLE III

Serum and muscle of rats fed normal diet

\begin{tabular}{|c|c|c|c|c|c|c|c|c|c|c|c|c|c|c|}
\hline $\begin{array}{l}\text { Num- } \\
\text { ber } \\
\text { of rats }\end{array}$ & Days* & Elevation & \multicolumn{2}{|c|}{ Per $\mathrm{L}$, of serum } & \multicolumn{2}{|c|}{$\begin{array}{l}\text { Per I, of serum } \\
\text { ultrafiltrate }\end{array}$} & \multicolumn{6}{|c|}{ Per 100 grams of fat-fre? muscle solids } & $\left(\mathrm{H}_{2} \mathrm{O}\right)_{c}$ & $(\mathrm{Na})_{i}$ \\
\hline \multirow{3}{*}{13} & \multirow{3}{*}{0} & \multirow{3}{*}{$\begin{array}{c}\text { feet } \times 10^{3} \\
0\end{array}$} & grams & $m \cdot M$ & $m M$ & $m M$ & grams & $m \cdot M$ & $m M$ & $m . M$ & $m \cdot M$ & grams & \multirow{3}{*}{$\begin{array}{l}m l \\
45\end{array}$} & \multirow{3}{*}{$\begin{array}{r}m M \\
3.1\end{array}$} \\
\hline & & & 925 & 4.0 & 113 & 147 & 340 & 6.1 & 9.7 & 48.7 & 32.4 & 15.3 & & \\
\hline & & & \pm 6 & \pm 0.8 & \pm 3.3 & \pm 3 & \pm 6 & \pm 0.6 & \pm 0.8 & \pm 1.1 & \pm 1.5 & \pm 0.2 & & \\
\hline 11 & 1 & 0 & \pm 5 & \pm 0.5 & \pm 4 & \pm 3 & \pm 8 & \pm 0.8 & \pm 0.4 & \pm 1.0 & \pm 0.8 & \pm 0.2 & 49 & 2.1 \\
\hline 4 & 7 & 0 & $\overline{951}$ & 4.4 & 113 & $\overline{143}$ & 353 & 8.5 & 11.7 & 44.0 & 33.0 & 15.2 & 66 & 2.2 \\
\hline 6 & 1,2 & 20 & 929 & 4.6 & 124 & 144 & 343 & 6.6 & 9.4 & 48.2 & 35.5 & 15.5 & 45 & 0.1 \\
\hline 3 & 7 & 20 & 931 & 5.6 & 124 & 153 & 349 & 8.1 & 14.5 & 48.2 & 34.6 & 15.6 & 57 & 5.8 \\
\hline 6 & 1,2 & 25 & 931 & 4.9 & 127 & 148 & 325 & 6.7 & 9.0 & 49.3 & 34.4 & 15.2 & 45 & 2.4 \\
\hline 3 & 7 & 25 & 945 & 5.6 & 138 & 145 & 342 & 9.1 & 12.0 & 45.0 & 32.5 & 15.1 & 59 & 3.5 \\
\hline 2 & $7 * *$ & 25 & 932 & 5.2 & 120 & 149 & 347 & 8.5 & 10.2 & 49.3 & 33.0 & 15.1 & 62 & 0.9 \\
\hline
\end{tabular}

* Days refers to duration of fast in the case of the first 3 groups and duration of the exposure to low atmospheric pressures in the remaining groups. Standard deviations are given for the controls but not for the others. The figures for the experimental group represent average values.

** Rats exposed to 25,000 feet for 7 days while receiving water containing 0.5 per cent $\mathrm{KCl}$ to drink.

TABLE IV

Serum and muscle of rats injected with DOCA

\begin{tabular}{|c|c|c|c|c|c|c|c|c|c|c|c|c|c|c|}
\hline \multirow{2}{*}{$\begin{array}{l}\text { Num- } \\
\text { ber } \\
\text { of rats }\end{array}$} & \multirow{2}{*}{ Days* } & \multirow{2}{*}{ Elevation } & \multicolumn{2}{|c|}{ Per $\mathrm{L}$ of serum } & \multicolumn{2}{|c|}{$\begin{array}{l}\text { Per } \mathrm{L} \text { of serum } \\
\text { uitrafiltrate }\end{array}$} & \multicolumn{6}{|c|}{ Per 100 grams of fat-free muscle solids } & \multirow{2}{*}{$\left.\left(\mathrm{H}_{2}\right)\right)_{\mathrm{C}}$} & \multirow{2}{*}{$(N a)$, } \\
\hline & & & $\mathrm{H}_{2} \mathrm{O}$ & $\mathrm{K}$ & {$[\mathrm{Cl}]$} & [Na] & $\mathrm{H}_{2} \mathrm{O}$ & $\mathrm{Cl}$ & $\mathrm{Na}$ & $\mathrm{K}$ & $\mathrm{P}$ & $\mathrm{N}$ & & \\
\hline \multirow{7}{*}{21} & & feet $\times 10^{3}$ & grams & $m M$ & $m M$ & $m M$ & grams & $m M$ & $m M$ & $m M$ & $m M$ & grams & $m l$. & $m M$ \\
\hline & 0 & 0 & 941 & 3.4 & 110 & 150 & 328 & 6.3 & 14.4 & 40.0 & 32.0 & 15.4 & 48 & 7.2 \\
\hline & & & \pm 6 & \pm 0.8 & \pm 3 & \pm 6 & \pm 9 & \pm 0.7 & \pm 1.5 & \pm 2.4 & \pm 1.1 & \pm 0.1 & & \\
\hline & 1 & 0 & $\overline{940}$ & 4.4 & 100 & 141 & 340 & 6.1 & 12.8 & 40.0 & 33.5 & 15.2 & 51 & 5.6 \\
\hline & 7 & 0 & 948 & 4.7 & 100 & 149 & 343 & 7.3 & 14.6 & 40.0 & 31 & 14.8 & 63 & 5.2 \\
\hline & 1,2 & 20 & 940 & 3.4 & 119 & 149 & 348 & 9.2 & 15.0 & 42.0 & 34 & 15.6 & 69 & 8.1 \\
\hline & 7 & 20 & 943 & 4.5 & 113 & 143 & 346 & 7.3 & 17.7 & 39.0 & 33 & 15.2 & 54 & 10.0 \\
\hline
\end{tabular}

* Days refers to the duration of the fast or exposure to low atmospheric pressures. The first 3 groups are the fed and fasted controls. All rats received DOCA for 14 days before as well as during the fast or exposure to low tensions of oxygen. 
TABLE V

Serum and muscle of rats receiving low $K$ diet

\begin{tabular}{|c|c|c|c|c|c|c|c|c|c|c|c|c|c|c|}
\hline \multirow{2}{*}{$\begin{array}{l}\text { Num- } \\
\text { ber } \\
\text { of rats }\end{array}$} & \multirow{2}{*}{ Days* } & \multirow{2}{*}{ Elevation } & \multicolumn{2}{|c|}{ Per $L$ of serum } & \multicolumn{2}{|c|}{$\begin{array}{l}\text { Per } L \text { of serum } \\
\text { ultrafiltrate }\end{array}$} & \multicolumn{6}{|c|}{ Per 100 grams of fat-free muscle solids } & \multirow{2}{*}{$\left(\mathrm{H}_{2} \mathrm{O}\right)$} & \multirow{2}{*}{$(\mathrm{Na})$, } \\
\hline & & & $\mathrm{H}_{2} \mathrm{O}$ & $\mathbf{K}$ & {$[\mathrm{Cl}]$} & [Na] & HsO & $\mathbf{C l}$ & $\mathbf{N a}$ & $\mathbf{K}$ & $\mathbf{P}$ & $\mathbf{N}$ & & \\
\hline $\begin{array}{l}15 \\
6 \\
6 \\
3 \\
6 \\
3\end{array}$ & $\begin{array}{c}0 \\
1,2 \\
7 \\
1,2 \\
7\end{array}$ & $\begin{array}{c}\text { feet } \times 100 \\
\\
20 \\
20 \\
25 \\
25\end{array}$ & $\begin{array}{l}\text { grams } \\
941 \\
\pm 1.2 \\
930 \\
946 \\
936 \\
936\end{array}$ & $\begin{array}{r}m M \\
2.5 \\
\pm 0.3 \\
4.5 \\
4.5 \\
3.3 \\
4.4\end{array}$ & $\begin{array}{l}m M \\
106 \\
\pm 4 \\
121 \\
130 \\
121 \\
124\end{array}$ & $\begin{array}{l}m M \\
146 \\
\pm 3 \\
151 \\
147 \\
148 \\
150\end{array}$ & $\begin{array}{l}\text { grams } \\
333 \\
\pm 6 \\
312 \\
339 \\
318 \\
323\end{array}$ & $\begin{array}{r}m M \\
6.6 \\
\pm 0.7 \\
6.8 \\
8.9 \\
5.9 \\
8.5\end{array}$ & \begin{tabular}{c|}
$m M$ \\
15.1 \\
\pm 1.0 \\
11.3 \\
13.1 \\
10.6 \\
13.1
\end{tabular} & $\begin{array}{c}m M \\
39.6 \\
\pm 2.1 \\
43.0 \\
44.3 \\
44.0 \\
41.0\end{array}$ & \begin{tabular}{c|}
$\boldsymbol{m M}$ \\
$\mathbf{3 2 . 0}$ \\
$\mathbf{\pm 0 . 9}$ \\
$\mathbf{3 3 . 0}$ \\
33.0 \\
35.0 \\
32.0
\end{tabular} & $\begin{array}{r}\text { grams } \\
15.1 \\
\pm 0.2 \\
15.2 \\
15.3 \\
15.1 \\
15.1\end{array}$ & $\begin{array}{l}m l . \\
53 \\
56 \\
60 \\
40 \\
60\end{array}$ & $\begin{array}{r}\boldsymbol{m M} \\
7.4 \\
2.8 \\
4.3 \\
4.6 \\
4.0\end{array}$ \\
\hline
\end{tabular}

* Days refers to the duration of the fast or exposure to low atmospheric pressures. The first group represents fed controls. All rats received the diet low in potassium for 14 days before the exposure.

intracellular sodium. It is:

$$
(\mathrm{Na})_{i}=(\mathrm{Na})_{t}-\frac{[\mathrm{Na}]_{0}\left(\mathrm{H}_{2} \mathrm{O}\right)_{e}}{1000}
$$

where $(\mathrm{Na})_{t}$ is intracellular sodium; $[\mathrm{Na}]_{e}$, the concentration in serum ultrafiltrate; and $\left(\mathrm{H}_{2} \mathrm{O}\right)_{e}$, the extracellular water. At each elevation, 3 animals were exposed for 1,2 , and 7 days. When there are no statistically different values on the first and second days, these results are combined. Fasting controls are given for the normal and DOCA groups.

\section{Serum analyses}

The data suggest that rats develop alkalosis in the serum during exposure to low atmospheric pressures. In the normal rats (Table III), the concentrations of chloride in serum ultrafiltrate rise from 113 to 120 , or more, $\mathrm{mM}$ per liter and this change is not accompanied by a significant change in serum sodium. Indirectly, these findings indicate that the concentration of bicarbonate in serum decreases. Not shown in the tables are analyses of 6 normal rats, exposed for 1,2, and 4 hours at 25,000 feet. Since these serums showed no changes, the alterations in serum sodium and chloride require between 4 and 24 hours' exposure to low atmospheric pressures before they are manifest. As may be seen from Tables III, IV, and $\mathrm{V}$, normal rats at sea level show higher serum chlorides than rats fed a diet low in potassium or those injected with DOCA. On fasting, rats receiving DOCA develop still lower concentrations of chloride in serum. However, on exposure to low atmospheric pressures, serum chloride in- creases practically as much in the rats on the diet low in potassium, or in those receiving DOCA, as in the normal rats similarly exposed. These findings at low atmospheric pressures represent the long recognised compensatory reactions accompanying deficit of carbon dioxide which accompany the overbreathing of anoxemia (11). The data show that neither deficit of body potassium nor injection of desoxycorticosterone acetate interferes with this reaction.

\section{Muscle analyses}

The muscles show certain changes in water content which are not primarily dependent on exposure to low atmospheric pressure. Thus, normal rats show an increase in extracellular water after a fast of 7 days and after an exposure for 7 days to low atmospheric pressure (see Table III). Rats receiving DOCA show an increase in extracellular water of muscle only during the first 2 days' exposure to low atmospheric pressure (see Table IV). The rats on the diet low in potassium show only questionable increase in extracellular water after 7 days' exposure at 20,000 or 25,000 feet elevation. Since similar changes can be produced in a few minutes by exercise (12), they are not regarded as a fundamental alteration in muscle composition. Within the fibers, certain muscles show changes which are manifested by alterations in the usual relationships between the concentrations of sodium, chloride, and potassium to each other and to the fat-free solids. In normal rats, muscle potassium varies between 47 and $49 \mathrm{mM}$ per 100 grams of fat-free solids but may decrease to $44 \mathrm{mM}$ without the appearance of low 
concentration of potassium in serum or significant increase in intracellular sodium (1). The data show this type of decrease in muscle potassium without increase in intracellular sodium in (1) normal rats fasted for 7 days and (2) normal rats after an exposure for 7 days at 25,000 feet. In the case of normal rats exposed to 25,000 feet for 7 days, the administration of 0.5 per cent potassium chloride in the drinking water prevents this loss of potassium but does not alter the evidences of distress at this low atmospheric pressure. Since normal rats at 25,000 feet refuse all food, loss of muscle potassium without increase in intracellular sodium is regarded as a result of fasting rather than anoxemia.

On the other hand, other experiments give evidence of increase in intracellular sodium which is apparently dependent on exposure to low atmospheric pressures. In the normal rats, the value for $(\mathrm{Na})_{i}$ is distinctly high after 7 days at 20,000 (see Table III). The increase in intracellular sodium occurs early as well as late in the rats treated with DOCA and is very marked after 7 days (see Table IV). Attention is directed to the facts that the rise in $(\mathrm{Na})_{i}$ is superimposed on an already high value in the DOCA rats and that no statistically significant fall in the already low value for potassium is found. Since similar rises in intracellular sodium are not found in the fasted DOCA rats at sea level, this finding is associated with anoxemia rather than loss of appetite.

As illustrated in Table $\mathrm{V}$, similar increase in intracellular sodium is only suggested in the rats on the diet low in potassium. In the first place, $(\mathrm{Na})_{i}$ starts at a high value and exposure to low atmospheric pressure leads to a decrease which is accompanied by an increase in muscle potassium. Since the only food offered was the diet low in potassium and this was taken poorly during the first days at 20,000 feet and refused almost entirely at 25,000 feet, the rise in muscle potassium represents retention of body potassium freed by consumption of tissues. The rise in $(\mathrm{Na})_{i}$ from the low value during the first days at 20,000 feet to a higher value after 7 days probably represents the same phenomenon as was observed in normal rats or those receiving DOCA. Attention is directed to the fact that initially the composition of the muscle is about the same in the rats given the diet low in potassium and in those receiving DOCA. Since the rise in $(\mathrm{Na})_{i}$ is greater in the DOCA rats, the initial composition of the muscle is not the cause of the size of the change. Furthermore, an increase did not develop with fasting alone in the DOCA rats. One may conclude, therefore, that injections of DOCA aggravate this accumulation of intracellular sodium which may be produced in normal rats by anoxemia.

\section{Liver analyses}

The liver analyses were undertaken because of the apparent vulnerability of the liver to anoxia and disturbances in circulation, such as shock and cardiac failure. The analyses for water and electrolyte were carried out on pooled samples of 3 livers after aliquots had been removed for determination of glycogen. The values for the latter are given as averages calculated per 100 grams of fat-free solids.

\section{Liver weight}

The data show distinct enlargement of the liver accompanying exposure to low atmospheric pressures. The finding is complicated by the fact that

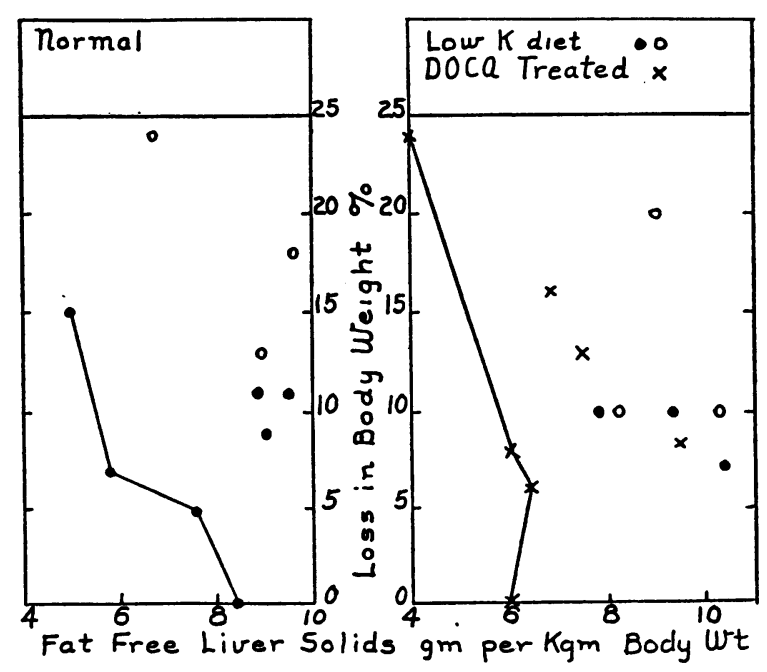

Fig. 3. Relation of Fat-Free Liver Solids to Losses OF Body WeIgHT

The points connected by lines represent data from fasted rats while the other points represent data from rats exposed to low atmospheric pressures. The dots and circles represent exposures to simulated elevations of 20,000 and 25,000 feet, respectively. The crosses represent DOCA treated rats exposed to 20,000 feet. 
fasting reduces liver size and in some experiments the two effects cancel one another.

In Figure 3, the fat-free solids in per cent of initial body weight are charted against loss in body weight expressed in grams per kilogram of initial weight. One part of the figure presents data on rats normal at the beginning of the experiment, while the other part gives data on the two types of rats depleted of body potassium. The points connected with lines represent data from fasted controls while the other points represent data from rats exposed to low atmospheric pressure.

The chart shows that the losses of body weight at low atmospheric pressure are not accompanied by decreases in liver substance except in the normal rats exposed for 7 days to 25,000 feet. In this case, the refusal of food leads to the same decrease in liver size as is found in the fasting rats. The other rats at reduced pressures show normal or enlarged livers. The size is greatest in rats on the diet low in potassium. The enlargement is not statistically significant unless comparison is made with the fasted rather than the fed controls. The same evidence of liver enlargement is found when water and fat are taken into account in comparing the various livers.

\section{Liver composition}

Table VI gives the composition of the livers. In fasting normal rats, the striking changes are the increase in liver fat on the first and second days and increase in liver water after 7 days. The partition of liver water cannot be calculated with certainty. ${ }^{8}$ In rats treated with DOCA, the effects of fasting are similar but with this difference. The fed controls receiving DOCA have high $\mathrm{Cl}, \mathrm{Na}$, and water, indicating high extracellular water. Fasting reduces the excessive extracellular water. Furthermore, after 1 week of fasting, the livers show a reduced concentration of potassium.

${ }^{8}$ Usually, it is unjustifiable to calculate the value of extracellular water from the liver chloride since the liver chloride is higher than the sodium, indicating considerable intracellular chloride. Neither is it justifiable to calculate extracellular water from liver sodium since there is considerable evidence of the presence of intracellular sodium (9). For these reasons, one cannot assign the changes in liver water to either of the phases of liver water with certainty.
TABLE VI

Liver electrolyte, water, and solids

\begin{tabular}{|c|c|c|c|c|c|c|c|c|c|}
\hline \multirow{2}{*}{$\underset{\text { ber }}{\text { Num- }}$} & \multirow{2}{*}{ Days } & \multicolumn{8}{|c|}{ Per 100 grams of fat-free solids } \\
\hline & & $\mathrm{H}_{2} \mathrm{O}$ & $\mathrm{Cl}$ & $\mathbf{N a}$ & $\mathbf{K}$ & $\mathbf{P}$ & $\mathbf{N}$ & Fat & Glycogen \\
\hline \multirow[b]{2}{*}{$\begin{array}{l}2 \\
3 \\
4\end{array}$} & & grams & $m M$ & $m M$ & Fastin & $\begin{array}{l}m M \\
g \mathrm{C} \text { Cont }\end{array}$ & $\begin{array}{l}\text { grams } \\
\text { trols }\end{array}$ & grams & grams \\
\hline & $\begin{array}{l}1 \\
2 \\
7\end{array}$ & $\begin{array}{l}290 \\
\pm 7.5 \\
296 \\
280 \\
324\end{array}$ & $\mid \begin{array}{r}11.0 \\
\pm 0.7 \\
13.3 \\
13.3 \\
11.6\end{array}$ & \begin{tabular}{|r}
10.4 \\
\pm 1.3 \\
10.5 \\
13.1 \\
9.2
\end{tabular} & \begin{tabular}{|l}
35.9 \\
\pm 2.3 \\
36 \\
38 \\
38
\end{tabular} & $\mid \begin{array}{l}40.5 \\
\pm 2.7 \\
41 \\
44 \\
44\end{array}$ & $\left|\begin{array}{r}12.7 \\
\pm 0.6 \\
13.9 \\
14.3 \\
13.2\end{array}\right|$ & $\left|\begin{array}{r}9 \\
11 \\
24 \\
6\end{array}\right|$ & $\begin{array}{l}3.4 \\
0.8 \\
3.1\end{array}$ \\
\hline $\begin{array}{l}6 \\
7 \\
8\end{array}$ & $\begin{array}{l}1 \\
2 \\
7\end{array}$ & $\begin{array}{r}334 \\
\pm 18 \\
256 \\
279 \\
289\end{array}$ & $\left|\begin{array}{r}13.4 \\
\pm 0.8 \\
11.0 \\
11.9 \\
12.2\end{array}\right|$ & $\mid \begin{array}{r}14.7 \\
\pm 1.3 \\
10.6 \\
11.2 \\
12.5\end{array}$ & $\begin{array}{l}\text { Fasti } \\
\begin{array}{|l|}39.9 \\
\pm 3.2 \\
34 \\
36 \\
25 \\
25\end{array}\end{array}$ & \begin{tabular}{|} 
ng DO \\
$\left|\begin{array}{|l}44.8 \\
\pm 3.1 \\
41 \\
42 \\
41\end{array}\right|$
\end{tabular} & $\begin{array}{l}\mathrm{CA} \\
\left|\begin{array}{r}14.2 \\
\pm 0.5 \\
13.5 \\
14.3 \\
14.0\end{array}\right|\end{array}$ & $\begin{array}{r}12 \\
4 \\
14 \\
7\end{array}$ & $\begin{array}{l}3.7 \\
0.1 \\
0.4 \\
1.2\end{array}$ \\
\hline $\begin{array}{r}9 \\
10 \\
11\end{array}$ & $\begin{array}{l}1 \\
2 \\
7\end{array}$ & $\begin{array}{l}263 \\
332 \\
265\end{array}$ & $\begin{array}{l}11.2 \\
12.3 \\
13.1\end{array} \mid$ & $\begin{array}{l}\mathbf{1} \\
9.2 \\
9.4\end{array}$ & $\begin{array}{l}\text { Normal } \\
\begin{array}{|l}\mathbf{3 0} \\
\mathbf{3 3} \\
\mathbf{3 3}\end{array}\end{array}$ & $\begin{array}{l}120,000 \\
\left|\begin{array}{l}35 \\
37 \\
37\end{array}\right|\end{array}$ & $\begin{array}{l}0 \text { feet } \\
\left|\begin{array}{l}12.3 \\
12.5 \\
13.1\end{array}\right|\end{array}$ & $\left|\begin{array}{r}5 \\
10 \\
15\end{array}\right|$ & \\
\hline $\begin{array}{l}12 \\
13 \\
14\end{array}$ & $\begin{array}{l}1 \\
2 \\
7\end{array}$ & $\begin{array}{l}263 \\
286 \\
293\end{array}$ & $\begin{array}{l}12.8 \\
14.4 \\
13.7\end{array} \mid$ & $\begin{array}{r}1 \\
\left|\begin{array}{r}11.6 \\
10.7 \\
11.8\end{array}\right|\end{array}$ & $\begin{array}{l}\text { DOCA } \\
\begin{array}{|l|l}33 \\
35 \\
35\end{array}\end{array}$ & $\begin{array}{l}20,000 \\
\left|\begin{array}{l}39 \\
41 \\
39\end{array}\right|\end{array}$ & $\begin{array}{l}0 \text { feet } \\
\left|\begin{array}{l}13.2 \\
13.9 \\
13.5\end{array}\right|\end{array}$ & \begin{tabular}{r|}
3 \\
14 \\
20
\end{tabular} & $\begin{array}{r}1.5 \\
12.1\end{array}$ \\
\hline $\begin{array}{l}15 \\
16 \\
17\end{array}$ & $\begin{array}{l}\mathbf{1} \\
\mathbf{2} \\
\mathbf{7}\end{array}$ & $\begin{array}{l}262 \\
267 \\
270\end{array}$ & $\begin{array}{l}12.0 \\
10.9 \\
13.6\end{array}$ & \begin{tabular}{|l|}
10.8 \\
10.6 \\
11.8
\end{tabular} & $\begin{array}{l}\text { Low } \\
\begin{array}{|l}36 \\
\mathbf{3 6} \\
\mathbf{3 6}\end{array}\end{array}$ & $\begin{array}{l}20,00 \\
\left|\begin{array}{l}38 \\
41 \\
43\end{array}\right|\end{array}$ & $\begin{array}{l}00 \text { feet } \\
\left|\begin{array}{l}12.2 \\
12.4 \\
12.9\end{array}\right|\end{array}$ & $\begin{array}{l}14 \\
20 \\
15\end{array}$ & $\begin{array}{r}12.9 \\
7.8 \\
4.3\end{array}$ \\
\hline $\begin{array}{l}18 \\
19 \\
20\end{array}$ & $\begin{array}{l}\mathbf{1} \\
\mathbf{2} \\
\mathbf{7}\end{array}$ & $\begin{array}{l}277 \\
268 \\
264\end{array}$ & \begin{tabular}{|l|}
13.1 \\
12.6 \\
14.4
\end{tabular} \mid & $\begin{array}{r}1 \\
\left|\begin{array}{r}12.9 \\
9.8 \\
8.5\end{array}\right|\end{array}$ & $\begin{array}{l}\text { Norma } \\
\begin{array}{|l}\mathbf{3 6} \\
\mathbf{3 6} \\
\mathbf{3 4}\end{array}\end{array}$ & $\begin{array}{l}125,000 \\
\left|\begin{array}{l}38 \\
41 \\
35\end{array}\right|\end{array}$ & $\begin{array}{l}0 \text { feet } \\
\left|\begin{array}{l}13.4 \\
12.9 \\
13.5\end{array}\right|\end{array}$ & $\begin{array}{r}12 \\
13 \\
7\end{array}$ & $\begin{array}{r}1.7 \\
12.7 \\
4.8\end{array}$ \\
\hline $\begin{array}{l}21 \\
22 \\
23\end{array}$ & $\begin{array}{l}1 \\
2 \\
7\end{array}$ & $\begin{array}{l}237 \\
313 \\
269\end{array}$ & $\begin{array}{r}8.7 \\
14.0 \\
14.5\end{array}$ & $\begin{array}{r}I \\
9.6 \\
12.6 \\
10.4\end{array}$ & $\begin{array}{l}\text { Low K } \\
\qquad \begin{array}{l}31 \\
\mathbf{3 5} \\
\mathbf{2 7}\end{array}\end{array}$ & $\begin{array}{l}25,000 \\
\left|\begin{array}{l}47 \\
49 \\
39\end{array}\right|\end{array}$ & $\begin{array}{l}\text { feet } \\
\left|\begin{array}{l}15.1 \\
15.4 \\
12.8\end{array}\right|\end{array}$ & $\begin{array}{r}21 \\
37 \\
7\end{array}$ & $\begin{array}{l}1.4 \\
8.6 \\
6.4\end{array}$ \\
\hline
\end{tabular}

When normal rats are exposed to low atmospheric pressures, the changes in liver composition are for the most part within the variations of the fed and fasted controls. Water is high in the livers of those exposed for 2 days at 20,000 feet. Note the high fat at both levels, probably chiefly an effect of poor appetite with the shift of liver metabolism to combustion of fat. The high liver glycogen after 2 days at 25,000 feet is evidence of the Evans (13 to 16) phenomenon. In all groups, the chloride tends to be higher than sodium and this difference is exaggerated in the rats kept at 25,000 feet. Since at this pressure there is increase in serum chloride and no change in serum sodium, the change in tissue chloride and sodium cannot be interpreted as indicating any fundamental change in the intracellular phase.

The exposure to low atmospheric pressure of rats receiving DOCA likewise produces no striking change, attributable to anoxemia, in the water and electrolyte pattern of the liver. Liver fat becomes high owing to fasting; and high glycogen 
after 7 days at 20,000 feet exhibits the Evans' phenomenon, since these rats were not eating although food was in the cages. The rats on the diet low in potassium show low liver water, $\mathrm{Na}$, and $\mathrm{Cl}$ after 1 day at 25,000 feet. This finding indicates loss of extracellular water. The high glycogen after 1 day at 20,000 feet is attributable to anoxemia, since the rats do not eat during the first day of exposure. After 7 days at 25,000 feet, there is decrease in concentration of liver potassium. Since a similar finding occurs in fasted rats treated with DOCA, the phenomena probably should be attributed to fasting rather than anoxemia. Thus, there are striking changes in liver size and increases in certain organic constituents. The increase in fat is related to poor appetite; the increase in glycogen, to deficit of carbon dioxide. However, no changes in water and electrolyte are directly attributable to anoxemia.

\section{COMMENT}

Certain of our findings suggest that overactivity of the adrenals is a feature of the reaction of rats to low atmospheric pressure. While the histological data do not prove that the disappearance of cortical lipid is brought about by an increased rate of discharge rather than a decreased rate of production, the fact that the histological changes are demonstrable within 2 hours suggests that increased rate of discharge is the correct explanation. Houssay, et al. (17), Selye (18), Dosne and Dalton (19), and Sarason (6) also attributed decrease of cortical lipids to activation of the cortex. The degree of distress produced by low atmospheric pressures was least in the rats fed a normal diet, intermediate in those fed the diet low in potassium, and greatest in those receiving DOCA. The extent of lipid depletion is, thus, proportioned to the evidences of distress. This relationship between distress and depletion of cortical lipids is also supported by the fact that, in each group, greater depletion of lipid was found in the rats exposed to 25,000 feet than in those exposed to 20,000 feet. If increased discharge of cortical lipid continues during long periods of exposure to low atmospheric pressure, production is so increased as to enable the adrenals to appear normal within a week.
Some previous work has suggested that enlargement of the adrenals accompanies exposure to low atmospheric pressure. Armstrong and Heim (20) report adrenal enlargement in rabbits exposed daily for 4 hours, over a period of 5 weeks, to a simulated elevation of 18,000 feet. Dohan (21) and Langley and Clarke (22) report enlargement after short exposures but their findings are dubious because of variations in the size of the animals and because losses in body weight were not properly taken into consideration. Cole and Harned (23) showed that adrenal weight varies directly with body weight and Mulinos and Pomerantz (5) and Jackson (4) found that adrenals maintained their size relatively well during inanition. From a review of the literature, Tepperman and Engel (24) thought cortical hypertrophy occurred under circumstances leading to increased metabolism of proteins. Sundstroem and Michaels (25) found no adrenal enlargement in rats except those exposed to pressures lower than $300 \mathrm{~mm} \mathrm{Hg}$. Enlargement of the adrenals is apparently not a necessary feature of the adjustment in relatively short time experiments, involving pressures at which acclimatization is possible.

The accumulation of sodium within the muscle fibres of rats exposed to low atmospheric pressure suggests overactivity of the adrenals. Rise in intracellular sodium and loss of intracellular potassium are readily produced by repeated injections of desoxycorticosterone acetate $(1,26,8)$ and can be produced by cortical extract and some other related compounds (27). In these cases, rise in sodium is accompanied by fall in potassium. Only accumulation of sodium was demonstrable in the present experiments. Since injection of desoxycorticosterone acetate at low atmospheric pressure exaggerated the retention of intracellular sodium without leading to greater reduction in muscle potassium, overproduction of cortical hormone may also be the explanation of the accumulation of intracellular sodium in experiments involving no injection of cortical compounds.

Whatever the explanation of the mechanism of the muscle changes, other factors are probably more important than the adrenals in bringing about most of the electrolyte changes in the body as a whole. First, adjustment of acid-base equilibrium is carried out by renal excretion of sodium 
and this process goes on in much the same way in our experiments, in the presence of potassium deficit or under the influence of injections of desoxycorticosterone acetate, as in normal rats. The cortical hormone can, therefore, play no primary role in this process. Second, sodium and potassium are excreted owing to fasting and our experiments indicate that fasting at sea level and exposure at 25,000 feet with its accompanying refusal of food lead to the same change in muscle composition. Our experiments give no data which would indicate that the adrenals play a rôle in this process. It should be pointed out that the kidneys are unable completely to reabsorb potassium from the glomerular filtrate and hence deficits of body potassium can be produced (1) by diets low in potassium in animals with normal kidneys $(28,1)$, and (2) by normal diets when the kidneys are under the influence of excessive amounts of desoxycorticosterone acetate or cortical extract $(1,26)$. Since fasting frees large quantities of body potassium, the low muscle potassium which was found after 7 days of fasting or 7 days at 25,000 feet is probably associated with increased rate of renal excretion of potassium. This assumption is supported by the fact that addition of $\mathrm{KCl}$ to the drinking water prevented the loss of muscle potassium in rats exposed for 1 week at 25,000 feet. This change of renal function could be produced by increased adrenocortical function. Since the same phenomenon did not develop at 20,000 feet, fasting must be superimposed on anoxemia to change the renal excretion of potassium.

Alkalosis apparently plays no rôle in the changes in muscle composition since Yannet (29) found no change in intracellular sodium or potassium in alkalosis due to low serum chloride and high bicarbonate.

Because of the crucial position of the liver in metabolism, evidences of disturbances in this organ are particularly important. Recent work in progress in this laboratory has shown that, within 1 to 2 hours after bleeding rats sufficiently to produce "irreversible shock," the liver exhibits changes in electrolyte composition indicating alteration of the normal distribution of $\mathrm{Na}$ and $\mathrm{K}$. This is manifested first by a disappearance of the excess of $\mathrm{Cl}$ over $\mathrm{Na}$ and then by a decrease in potassium and increase in sodium. During the exposure of rats to low atmospheric pressures, analogous changes are not discovered. This finding is further evidence that the liver is not as sensitive to arterial as to venous unsaturation.

The data should not be interpreted to indicate that the liver is unaffected, for the changes in liver size are definite but not reflected in changes in water and electrolytes per unit of fat-free solids. Yannet (29) found, in cats, no changes in liver water and electrolyte, attributable to alkalosis. Furthermore, water and electrolyte of the liver per unit of fat-free solids show no variations with loss of extracellular electrolyte from the body (9), with repeated injections of desoxycorticosterone acetate (8), or with feeding of diets low in potassium. Thus, the liver cells seem able to protect their internal composition from certain alterations of their environment, such as changes in concentration of extracellular electrolyte, blood $\mathrm{pH}$, and arterial unsaturation. Nevertheless, the liver undergoes changes in organic composition, such as increase in fat with fasting, which explains the fat changes reported in this study, and increase in glycogen accompanying exposure to low atmospheric pressure, which is illustrated much better in previous studies than in our data $(13,15,16)$. The increase in size does not seem to be dependent on chronic passive congestionat least histological sections do not confirm this supposition. Perhaps the variations in liver composition (30) are so great with the various changes in metabolic activity under normal circumstances that alterations in water and electrolyte are overshadowed in most pathological conditions. On the other hand, changes in liver water and electrolyte may not develop until a more or less complete metabolic breakdown occurs. The latter state, of course, would be found only shortly before death.

From a practical point of view, great importance should be attached to the evidence that exposure to low atmospheric pressure aggravates the tendency of rats receiving desoxycorticosterone acetate to develop myocardial lesions. That this phenomenon is connected with accelerated loss of potassium is indicated by work in progress in our laboratory. It has been shown that the combination of a diet low in potassium with injections of desoxycorticosterone produces demonstrable histological lesions in the heart in 4 to 7 days, whereas either procedure alone takes more than 2 weeks. 
The exaggeration of the accumulation of intracellular sodium in muscle of rats receiving desoxycorticosterone acetate while being exposed to low atmospheric pressure may also be an undesirable effect of this steroid. Apparently, at low atmospheric pressures, excessive response to the renal factor of the cortical hormone is not desirable and may even be dangerous. This conclusion does not exclude the possibility that adjustment to low atmospheric pressures may be promoted by an excess of the glycogenic factor of the adrenal cortex. However, the proof for such an advantage can hardly be based on restoring the deficiencies of adrenalectomized animals but must come from evidence that animals having no deficiencies do better with an amount of hormone that is in excess of that which such animals can produce.

\section{SUMMARY}

Rats were exposed to atmospheric pressures equivalent to elevations of 20 and 25 thousand feet. Three groups were studied: (1) normal rats, (2) rats on a diet low in potassium, and (3) rats which received desoxycorticosterone acetate for 14 days before as well as during exposure to low atmospheric pressure.

Histological evidence of depletion of adrenal cortical lipid was found starting within 2 hours and reaching a maximum about the 48th hour of exposure. Recovery of cortical lipid is apparently complete in 7 days, even while the rats are continuously exposed to a level equivalent to 25,000 feet. Fasting alone does not produce similar changes. The extent of the depletion of lipid varies directly with the evidences of distress, being greatest in rats receiving desoxycorticosterone acetate, intermediate in those on the diets low in potassium, and least in those on the normal diet. Changes in adrenal size are not statistically demonstrated if adrenal weights are related to initial body weights. An exception is found in that moderate enlargement is demonstrable in rats on a diet low in potassium, after exposure for 1 or 2 days at 25,000 feet.

The tendency of desoxycorticosterone acetate to produce cardiac lesions is aggravated by exposure to low atmospheric pressures.

Decrease in muscle potassium is found in rats fasted for 7 days or kept at a pressure equivalent to an elevation of 25,000 feet for 7 days. This finding is considered a result of fasting. On exposure to low atmospheric pressure, normal rats and those receiving DOCA show an increase in intracellular sodium of muscle. Anoxemia seems to promote this change. No decrease in muscle potassium accompanies this increase in intracellular sodium.

Changes in liver composition (except increase in liver glycogen) can be related to fasting but not to the direct effects of low atmospheric pressure. On the other hand, exposure to low atmospheric pressure frequently induces enlargement of the liver.

\section{BIBLIOGRAPHY}

1. Miller, H. C., and Darrow, D. C., Relation of muscle electrolyte to alterations in serum potassium and to toxic effects of injected potassium chloride. Am. J. Physiol., 1940, 130, 747.

2. Harrison, H. E., and Darrow, D. C., The distribution of body water and electrolytes in adrenal insufficiency. J. Clin. Invest., 1938, 17, 77.

3. Bennett, H. S., Life history and secretion of cells of adrenal cortex of cat. Am. J. Anat., 1940, 67, 151.

4. Jackson, C. M., Effects of acute and chronic inanition upon the relative weights of various organs and systems of adult albino rats. Am. J. Anat., 1915, 18,75 .

5. Mulinos, M. G., and Pomerantz, L., Hormonal influences on the weight of the adrenal in inanition. Am. J. Physiol., 1941, 132, 368.

6. Sarason, E. L., The morphologic changes in the rat's adrenal cortex under various experimental conditions. Arch. Path., 1943, 35, 373.

7. Durlacher, S. H., Darrow, D. C., and Winternitz, M. C., Effect of low potassium diet and of desoxycorticosterone acetate upon renal size. Am. J. Physiol., 1942, 136, 346.

8. Darrow, D. C., and Miller, H. C., The production of cardiac lesions by repeated injections of desoxycorticosterone acetate. J. Clin. Invest., 1942, 21, 601.

9. Yannet, H., and Darrow, D. C., The effect of depletion of extracellular electrolytes on the chemical composition of skeletal muscle, liver, and cardiac muscle. J. Biol. Chem., 1940, 134, 721.

10. Manery, J. F., Danielson, I. S., and Hastings, A. B., Connective tissue electrolytes. J. Biol. Chem., 1938, 124, 359.

11. Haldane, J. S., Acclimatisation to high altitudes. Physiol. Rev. 1927, 7, 363.

12. Miller, H. C., and Darrow, D. C., Relation of serum and muscle electrolyte, particularly potassium, to voluntary exercise. Am. J. Physiol., 1941, 132, 801.

13. Evans,' G., The effect of low atmospheric pressure on the glycogen content of the rat. Am. J. Physiol., 1934, 110, 273. 
14. Evans, G., The adrenal cortex and endogenous carbohydrate formation. Am. J. Physiol., 1936, 114, 297.

15. Nims, L. F., et al., Conference on factors producing hypertrophy of the adrenal cortex in animals. Report to the Josiah Macy, Jr. Foundation, 1942.

16. Lewis, R. A., Thorn, G. W., Koepf, G. F., and Dorrance, S. S., The rôle of the adrenal cortex in acute anoxia. J. Clin. Invest., 1942, 21, 33.

17. Houssay, B. A., Biasotti, A., Mazzocco, P., and Sammartino, R., Action de l'extrait antéro-hypophysaire sur les surrénales. Compt. rend. Soc. de biol., 1933, 114, 737.

18. Selye, H., Studies on adaptation. Endocrinology, 1937, 21, 169.

19. Dosne, C., and Dalton, A. J., Changes in the lipoid content of the adrenal gland of the rat under conditions of activity and rest. Anat. Rec., 1941, 80, 211.

20. Armstrong, H. G., and Heim, J. W., The effect of repeated daily exposures to anoxemia. J. Aviation Med., 1938, 9, 92.

21. Dohan, F. C., Effect of low atmospheric pressure on the adrenals, thymus and testes of rats. Proc. Soc. Exper. Biol. and Med., 1942, 49, 404.

22. Langley, L. L., and Clarke, R. W., The reaction of the adrenal cortex to low atmospheric pressure. Yale J. Biol. and Med., 1942, 14, 529.
23. Cole, V. V., and Harned, B. K., Adrenal and pituitary weights in rats with reduced glucose tolerance. Endocrinology, 1942, 30, 146.

24. Tepperman, J., and Engel, F. L., Metabolic determinants of adrenal size and function. A review of adrenal cortical hypertrophy. Prepared for Josiah Macy, Jr. Foundation, New York City, 1942.

25. Sundstroem, E. S., and Michaels, G., The adrenal cortex in adaptation to altitude, climate and cancer. In the Memoirs of the University of California, vol. 12, University of California Press, Berkeley, 1942.

26. Ferrebee, J. W., et al., Certain effects of desoxycorticosterone: The development of "diabetes insipidus" and the replacement of muscle potassium by sodium in normal dogs. Am. J. Physiol., 1941, 135, 230.

27. Miller, H. C., Effect of the injection of sex hormones on serum and muscle electrolyte of rats. Endocrinology, 1943, 32, 443.

28. Heppel, L. A., Electrolytes of muscle and liver in potassium-depleted rats. Am. J. Physiol., 1939, 127, 385.

29. Yannet, H., The effect of alkalosis on the chemical composition of brain, skeletal muscle, liver, and heart. J. Biol. Chem., 1940, 136, 265.

30. Fenn, W. O., The deposition of potassium and phosphate with glycogen in rat livers. J. Biol. Chem., 1939, 128, 297. 